\title{
Association between individual, work-related and organizational factors and adherence to standard precautions
}

\author{
Associação entre fatores individuais, relativos ao trabalho e \\ organizacionais com a adesão às precauções padrão \\ Asociación entre factores individuales, laborales y organizacionales \\ con la adherencia a las precauciones estándar

\section{Quézia Boeira da Cunha \\ Etiane de Oliveira Freitas ${ }^{\mathrm{b}}$ \\ Tânia Solange Bosi de Souza Magnago ${ }^{b}$ \\ Maria Meimei Brevidellic \\ Mariana Pellegrini Cesar ${ }^{a}$ \\ Silviamar Camponogarab}

How to cite this article:

Cunha QB, Freitas EO, Magnago TSBS, Brevidelli MM, Cesar MP, Camponogara S. Association between individual, work-related and organizational factors and adherence to standard precautions. Rev Gaúcha Enferm. 2020;41:e20190258. doi: https://doi.org/10.1590/19831447.2020.20190258

\footnotetext{
a Universidade Federal de Santa Maria (UFSM), Programa de Pós-Graduação em Enfermagem. Santa Maria, Rio Grande do Sul, Brasil.

• Universidade Federal de Santa Maria, Departamento de Enfermagem. Santa Maria, Rio Grande do Sul, Brasil.

Universidade Paulista (UNIP), Instituto de Ciências da Saúde. São Paulo, São Paulo, Brasil.
}

\section{ABSTRACT}

Objective: To verify the association between individual, work-related and organizational factors with adherence to standard precautions

Method: Cross-sectional study, carried out from January to June 2016 with 602 nursing workers from a university hospital. Ten Likert-type psychometric scales were used, with 57 items, organized in three domains: individual, work-related and organizational factors. Data were analyzed with descriptive and inferential statistics.

Results: The adherence to the standard precautions obtained a mean intermediate score $(4.30 \pm 1.03)$ and a positive correlation with the Risk Personality Scales $(r=0.136, p<0.0001)$, Prevention Efficacy $(r=0.109, p<0.0001)$, Obstacles to follow the precautions $(r=0.394, p<0.0001)$, PPE availability $(r=0.189 p<0.0001)$, Safety Climate $(r=0.325, p<0,0001)$ and Training on Prevention of Occupational Exposure $(r=+0.308, p<0.0001)$.

Conclusion: Adherence to standard precautions is associated with individual, work-related, and organizational factors.

Keywords: Universal precautions. Occupational risks. Containment of biohazards. Security measures. Nursing.

\section{RESUMO}

Objetivo: Verificar a associação entre fatores individuais, relativos ao trabalho e organizacionais com adesão às precauções-padrão. Método: Estudo transversal, realizado de janeiro a junho de 2016 com 602 trabalhadores de enfermagem de um hospital universitário. Foram utilizadas 10 escalas psicométricas do tipo Likert, com 57 itens, organizadas em três domínios: fatores individuais, relativos ao trabalho e organizacionais. Os dados foram analisados com estatística descritiva e inferencial.

Resultados: A adesão às precauções-padrão obteve escore médio intermediário $(4,30 \pm 1,03)$ e apresentou correlação positiva com as escalas de Personalidade de Risco ( $r=0,136, p<0,0001)$, Eficácia da Prevenção $(r=0,109, p<0,0001)$, Obstáculos para seguir às precauções $(r=0,394, p<0,0001)$, Disponibilidade de EPI $(r=0,189 p<0,0001)$, Clima de Segurança $(r=0,325, p<0,0001)$ e Treinamento em Prevenção da Exposição Ocupacional ( $r=+0,308, p<0,0001)$.

Conclusão: A adesão às precauções padrão está associada a fatores individuais, relacionados ao trabalho e organizacionais.

Palavras-chave: Precauções universais. Risco ocupacional. Contenção de riscos biológicos. Medidas de segurança. Enfermagem.

\section{RESUMEN}

Objetivo: Verificar la asociación entre los factores individuales, relacionados con el trabajo y organizacionales con el cumplimiento de las precauciones estándar.

Método: Estudio transversal, realizado de enero a junio de 2016 con 602 trabajadores de enfermería de un hospital universitario. Se utilizaron diez escalas psicométricas tipo Likert, con 57 ítems, organizados en tres dominios: individual, relacionado con el trabajo y factores organizativos. Los datos fueron analizados con estadística descriptiva e inferencial.

Resultados: La adherencia a las precauciones estándar obtuvo una puntuación media intermedia (4.30 \pm 1.03 ) y una correlación positiva con las Escalas de Personalidad de Riesgo ( $r=0.136, p<0.0001)$, Eficacia de la Prevención $(r=0.109), p<0.0001)$, Obstáculos para seguir las precauciones ( $r=0.394, p<0.0001)$, Disponibilidad de PPE $(r=0.189 p<0.0001)$, Clima de seguridad ( $r$ $=0.325, p<0,0001)$ y Capacitación en Prevención de la Exposición Ocupacional $(r=+0.308, p<0.0001)$.

Conclusión: La adherencia a las precauciones estándar está asociada con factores individuales, relacionados con el trabajo y organizativos.

Palabras clave: Precauciones universales. Riesgos laborales. Contención de riesgos biológicos. Medidas de seguridad. Enfermería. 


\section{口INTRODUCTION}

Due to the nature of nursing profession, these professionals are the most likely workers to be exposed to biological risks in the hospital setting. They suffer more accidents in the hospital setting than other health professionals, and are also the ones with the highest rates of HIV seroconversion ${ }^{(1)}$.

According to the World Health Organization (WHO), the annual number of occupational percutaneous exposures among health professionals is estimated at over three million worldwide. Also, severe percutaneous exposures account for approximately 66,000 cases of hepatitis B virus (HBV) infection, 16,000 cases of hepatitis C (HCV) infection and 1,000 cases of human immunodeficiency virus (HIV) infection among health professionals. Overall, occupational HBV and HCV infections are estimated to account for about 37\% and 39\%, respectively, of all infections among healthcare workers ${ }^{(2)}$. Standard precautions (SP) are recommendations to protect health care workers while handling medical and hospital supplies and assisting patients, during the delivery of care, based on the assumption that all body fluids (except sweat) may be contaminated with infectious agents $s^{(3)}$. These measures aim to prevent infection, creating a protective barrier against the transmission of pathogens from infected patients to healthcare workers.

According to the literature, several factors may interfere with the adherence of health professionals to standard precautions. These factors may be related to the individual, e.g. professional's awareness and knowledge, his/her perception of the risks and effectiveness of protective measures, as well as subjective aspects of the worker, such as the conflict between different demands, for example, saving a patient's life or taking care of his/her own protection. Work-related factors may also influence adherence to SP, such as high workload and lack of time to put on personal protective equipment (PPE). The structural support provided by the institution, as well as the availability of PPE, adequate physical structure and inspection are also organizational factors that may interfere with the adoption of standard precautions by health care workers ${ }^{(4)}$.

Although these factors related to adherence to standard precautions are known, an in-depth analysis of them is needed to understand these phenomena. Thus, the present study aimed to verify the association between individual, work-related and organizational factors and adherence to standard precautions among nursing workers from a university hospital.
The results of this study may provide support for the promotion of safe care practices, through the planning of actions to improve adherence to standard precautions (SP) in hospital institutions.

\section{- METHOD}

Cross-sectional analytical study with a quantitative approach with nursing workers (including nurses, nurse technicians and nurse assistant)s from a university hospital in southern Brazil.

This study includes results of the dissertation entitled "Adherence to standard precautions by nursing workers of a university hospital: a mixed methods research" submitted to the Nursing Graduate Program of Universidade Federal de Santa Maria ${ }^{(5)}$.

The study population consisted of 793 nursing workers. Inclusion criteria were professionals performing direct patient care duties and who have been performing their work activities in the current unit for six months or longer. A six-month period was considered the minimum amount of time needed by health professionals to adapt to their work sector, since the hospital had recently undergone restructuring, with the hiring and relocation of many workers. Exclusion criteria were workers on leave or absent for any reason during the data collection period and/or who were attached to the research group that conducted the investigation. Based on these criteria, 685 workers were able to participate in the study, and of these, 21 refused to participate. Of the 664 workers who agreed to participate, 602 returned their questionnaires completed. These were the study participants - $88 \%$ of the eligible population. Sample size calculation was not performed, since all nursing workers, according to the inclusion criteria, were invited to participate in the study.

The project complied with the stipulations of Resolution $466 / 2012$ on guidelines and rules for research involving humans and was approved by the Research Ethics Committee of Universidade Federal de Santa Maria - UFSM - under Protocol No. 45318815.0.0000.5346. The participants were contacted in the workplace and invited to participate in the study, after being fully informed about the objectives of the study and assured of the confidentiality of their responses. After expressing their consent by signing the Informed Consent Form, the participants received instructions for completing the questionnaire. The completed questionnaires were delivered by the participants to the researcher at an agreed-upon time and day. To ensure the participants' 
anonymity, the completed questionnaires were identified only with numbers corresponding to the order in which they were included in the study.

Data was collected from January to June 2016 with the use of two instruments: a questionnaire survey of Sociodemographic and Professional Variables (elaborated by the researchers) and a questionnaire of Variables Related to Standard Precautions that was translated into Portuguese and validated for the Brazilian context by Brevidelli and Cianciarullo(6). This instrument consists of 10 Likert-type scales with 57 items, with response options ranging from 1 (fully agree/always) to 5 (fully disagree/never). The scales of this instrument are organized into three domains: $1^{\text {st }}$ ) Individual Factors: comprise the items related to the Questionnaire of Sociodemographic and Professional Data, Adherence to Standard Precautions Scale, Scale of knowledge about Occupational HIVTransmission, Risk Perception Scale, Risk Propensity Scale and Prevention Effectiveness Scale; $\left.2^{\text {nd }}\right)$ Work-related Factors: Scale of Barriers to Compliance with Standard Precautions and Workload Scale: $3^{\text {rd }}$ ) Organizational Factors: Safety Climate Scale, Availability of PPE Scale and Training on Prevention of HIV Exposure Scale.

All scales obtained a minimum and maximum score ranging from 1 to 5 , and the responses were scored considering the mean scores obtained by the participants. These mean scores were classified into High ( $\geq 4.5$ ); Intermediate (3.5 to 4.49); and Low (<3.5), according to the authors ${ }^{(6)}$.

The mean score obtained in the Adherence to Standard Precautions Scale was considered the dependent variable of the study. The mean scores of the other scales that comprise individual factors, work-related factors and organizational factors, as well as the sociodemographic and professional variables of nursing workers were considered as independent variables.

Data was organized in a spreadsheet in database format using Excel, version 6.4, through double data entry. After checking for errors and inconsistencies in typing, data analysis was performed using PASW Statistics (Predictive Analytics Software, from SPSS Inc., Chicago - USA) version 18.0.

Qualitative variables were presented in absolute and relative values. Descriptive statistics was used in the presentation of quantitative variables: mean and standard deviation. Cronbach's alpha coefficient of $\geq 0.6$ was used for checking the internal consistency of the scales. Data normality and homogeneity was verified with Kolmogorov-Smirnov tests. Pearson's Correlation Coefficient ( $r$ ) was used to measure the association between the variables. Chi-square test was used in bivariate analysis. Results were considered statistically significant when $\mathrm{p}<0.05$, with a $95 \%$ confidence interval.

\section{口ESULTS}

Of the nursing workers who participated in the study, 186 (31.3\%) were nurses; 324 (54.4\%) nurse technicians and 85 (14.3\%) nurse assistants. Most participants: 519 (87.5\%) were women. Age ranged from 20 to 69 years, with a mean age of $41( \pm 9.46)$ years. Also, 212 (37.6\%) were aged 31-40 years. Regarding the length of time in the profession, it ranged from 6 months to 40 years, with an average of 15 ( \pm 9.23$)$ years. Regarding the number of permanent jobs of the participants, most 538 (90.9\%) had one employment contract. Regarding training on standard precautions, 412 (70.3\%) professionals said they received training at the hospital.

The values obtained for Cronbach's alpha coefficient in this study ranged from 0.650 to 0.905 , within the acceptable range for the internal consistency of scales. However, this analysis showed that removal of item 11 of the SP Adherence Scale and item 1 of the Prevention Effectiveness Scale increased Cronbach's alpha coefficient values. Therefore, these items were excluded from the analysis to maintain the internal consistency of these constructs.

Given the classification of the scores into High ( $\geq 4.5$ ); Intermediate (3.5 to 4.49); and Low ( $<3.5$ ), no high mean score was obtained in any of the scales. On the SP Adherence Scale, the mean score obtained was intermediate (4.30 SD \pm 1.03 ), as well as the overall score of individual factors ( $4.25 \mathrm{SD} \pm$ 0.99 ), and of work-related factors (3.86 SD \pm 1.01 ). As for the overall score of organizational factors, they were classified into low (3.37 SD \pm 1.07 ).

The existence of correlations between the mean score of adherence to SP (dependent variable) and individual, work-related and organizational factors (independent variables) is shown in Chart 1.

The mean SP Adherence score showed a weak but significant correlation with individual factors and a moderate and significant correlation with work-related and organizational factors.

The correlations between the mean score of Adherence to SP and the mean scores of the other scales that make up the instrument of Variables Related to Standard Precautions are shown below (Chart 2).

The mean score of Adherence to SP showed a weak, though significant correlation with the scales Risk Propensity, Prevention Effectiveness, and Availability of PPE. There was a moderate and significant correlation between the score of Adherence to SP and the scales of Barriers to Compliance with Standard Precautions, Safety climate and Training on Prevention of HIV Exposure. 
For the analysis of the association between the level of adherence to SP and sociodemographic/ professional variables, the participants were divided into three groups, according to the level of adherence to SP: high, intermediate or low. The level of adherence to SP was found to be significantly higher in the group that reported having received training on standard precautions at the hospital (Chi-square test $11.550 \mathrm{p}=0.003)$. This result is shown in Chart 3 .

The other sociodemographic variables analyzed, such as gender, age, professional occupation, length of professional training and employment contract were not associated with the level of adherence to SP in the studied population.

\begin{tabular}{|c|c|c|}
\hline FACTORS & & ADHERENCE TO SP \\
\hline \multirow{2}{*}{ INDIVIDUAL } & $\mathrm{R}$ & $\mathbf{+ 0 . 1 6 5}$ \\
\cline { 2 - 3 } & $\mathrm{P}$ & $<0.0001^{*}$ \\
\cline { 2 - 3 } & $\mathrm{R}$ & $\mathbf{+ 0 . 3 9 1}$ \\
& $\mathrm{P}$ & $<0.0001^{*}$ \\
\cline { 2 - 3 } ORGANIZATIONAL & $\mathrm{R}$ & $\mathbf{+ 0 . 3 3 5}$ \\
\cline { 2 - 3 } & $\mathrm{P}$ & $<0.0001^{*}$ \\
\hline
\end{tabular}

Chart 1- Pearson's correlation ( $r$ ) between the overall individual, work-related and organizational factors scores and the mean score of adherence to SP ( $n=602)$. Brazil - RS, 2016.

Source: Research data, 2016.

\begin{tabular}{|c|c|c|c|c|c|c|c|c|c|c|c|}
\hline \multirow{2}{*}{\multicolumn{2}{|c|}{ FACTORS }} & \multicolumn{5}{|c|}{ INDIVIDUAL } & \multicolumn{2}{|c|}{ WORK-RELATED } & \multicolumn{3}{|c|}{ ORGANIZATIONAL } \\
\hline & & ASP & PERS & PE & RP & KOT & BAR & WL & SC & TR & AVAIL \\
\hline \begin{tabular}{|l} 
ADHERENCE \\
TO SP
\end{tabular} & $\begin{array}{l}r \\
p\end{array}$ & +1 & $\begin{array}{l}+\mathbf{0 . 1 3 6} \\
<0.001^{*}\end{array}$ & $\begin{array}{l}+\mathbf{0 . 1 0 9} \\
<0.001^{*}\end{array}$ & $\begin{array}{c}+0.068 \\
0.094\end{array}$ & $\begin{array}{c}+0.097 \\
0.016\end{array}$ & $\begin{array}{l}+\mathbf{0 . 3 9 4} \\
<0.001^{*}\end{array}$ & $\begin{array}{c}+0.046 \\
0.250\end{array}$ & $\begin{array}{l}+\mathbf{0 . 3 2 5} \\
<0.001^{*}\end{array}$ & $\begin{array}{l}+\mathbf{0 . 3 0 8} \\
<0.001^{*}\end{array}$ & $\begin{array}{l}+\mathbf{0 . 1 8 9} \\
<0.001^{*}\end{array}$ \\
\hline
\end{tabular}

Chart 2 - Pearson's correlation ( $r$ ) between the individual, work-related and organizational factor scales and the SP adherence scale $(n=602)$. Brazil - $R S, 2016$

Source: Research data, 2016.

Legend: ASP - Adherence to SP; PERS - Risk propensity; PE - Prevention effectiveness; RP - Risk Perception; KOT - Knowledge of Occupational Transmission; BAR - Barriers to Compliance with SP:WL Work Load; SC - Safety Climate; TR-Training on occupational prevention; AVAIL - Availability of PPE

\begin{tabular}{|c|c|c|c|c|c|c|c|}
\hline & \multicolumn{6}{|c|}{ CLASSIFICATION OF ADHERENCE TO SP } & \multirow{3}{*}{ TOTAL } \\
\hline & \multicolumn{2}{|c|}{ HIGH } & \multicolumn{2}{|c|}{ INTERMEDIATE } & \multicolumn{2}{|c|}{ LOW } & \\
\hline & $\mathbf{F}$ & $\%$ & $\mathbf{F}$ & $\%$ & $\mathbf{F}$ & $\%$ & \\
\hline \multicolumn{8}{|l|}{ TRAINING ON SP } \\
\hline Received training & 184 & 44.7 & 220 & 53.4 & 8 & 1.9 & 412 \\
\hline Did not receive training & 52 & 29.9 & 116 & 66.7 & 6 & 3.4 & 174 \\
\hline TOTAL & \multicolumn{2}{|c|}{236} & \multicolumn{2}{|c|}{336} & \multicolumn{2}{|c|}{14} & 586 \\
\hline
\end{tabular}

Chart 3 - Distribution of nursing workers according to training on SP and SP Adherence rating. Brazil - RS, 2016. $\left(n=586^{*}\right)$ Source: Research data, 2016

$p=0.003$

*Total number of workers that answered the item "Received training on SP" 


\section{DISCUSSION}

The present study found only partial compliance with $\mathrm{SP}$ by the nursing workers of the institution. Moreover, adherence to SP was associated with individual, work-related and organizational factors. Some authors ${ }^{(6-8)}$ corroborate these findings in studies that demonstrate the influence of the referred factors on adherence to SP.

There was a significant linear correlation between adherence to SP and these factors. Thus, the lower the risk propensity of the workers; the greater the perception of prevention effectiveness; the higher the perception of availability of PPE; the lower the perception of barriers to compliance with SP; the better the perception of safety climate; and the better the perception of the training received, the better the compliance to SP.

According to the relevant literature, workers are often not aware of dangerous workplace situations that expose them to risks and excessive workloads ${ }^{(9)}$. The way workers perceive reality is materialized in practices that are often inadequate from the point of view of occupational safety. Thus, actions related to risk perceptions and propensity should be promoted, so that workers become aware that preserving their health is a priority ${ }^{(9)}$.

The way the subjects perceive the effectiveness of preventive actions was also associated with adherence to SP.The literature corroborates this finding by suggesting that behavioral beliefs (perceived benefits and barriers) are important in predicting preventive health behaviors, even surpassing the perception of severity and susceptibility to diseases ${ }^{(10)}$. Therefore, the training provided to workers should be more than merely informative - e.g. listing the risks to which workers are exposed - and broaden the perception of the benefits provided by compliance with standard precautions ${ }^{(10)}$.

Regarding work-related factors, the workers' perception of work barriers to compliance with safety recommendations had a great impact on adherence to SP. Thus, the fewer the barriers perceived, the better the adherence to SP. Some aspects perceived by workers as barriers to compliance with safety recommendations include lack of readily available PPE, excessive workload, interference with the use of SP in the execution of work, patients' needs that are perceived as a priority, among others.

These findings are corroborated by a study conducted in Nigeria ${ }^{(11)}$ which identified the following main barriers to compliance with standard precautions: lack of PPE, carelessness and lack of information about SP, low perception of the risk of blood-borne pathogens, lack of time, workers' inability to perform their tasks when they wear PPE and uncooperative patients.
Regarding organizational factors, all aspects related to this domain were correlated with adherence to $\mathrm{SP}$, and thus are key for the understanding of the topic investigated in this study. One aspect is workers' perceptions of the safety climate in their workplace, which can be assessed by the management's commitment to worker safety in the organization.

Workers' perception is one way of assessing the safety climate, which is one of the measurable components of an institution's safety culture, since assessing attitudes and values is more difficult ${ }^{(12)}$. Some authors ${ }^{(7)}$ reported the existence of an unsatisfactory safety climate in health institutions where workers' perception of the safety of their work environment is negative, demonstrating that management actions to support safety are weak in different work contexts in the hospital. Thus, managers must promote work environments where barriers to the adoption of safety measures are effectively reduced ${ }^{(13)}$.

The perception of adequate PPE availability is also associated with better adherence to SP. This finding is consistent with a study ${ }^{(8)}$ conducted in a psychiatric hospital in Brazil, which also found a correlation $(r=+0.643 ; p=0.000)$ between adherence to SP and availability of PPE, indicating that this is a key factor in the promotion of safety practices. International studies ${ }^{(14)}$ also indicate that lack of resources and unavailability of PPE in the workplace make it difficult for workers to comply with SP in many situations.

Education in the health care setting was also strongly highlighted in the present study as an important factor to improve adherence to SP. In this regard a study ${ }^{(15)}$ conducted in China reported that effective preventive actions can promote the use of standard precautions and raise the team's awareness of the need for behavioral changes. Likewise, other studies ${ }^{(14,16-17)}$, including a multicenter study with 4,439 participants in France ${ }^{(18)}$ recommended investments in educational programs on SP for health professionals after detecting a significant deficit of knowledge among these professionals.

Moreover, a randomized experimental study ${ }^{(19)}$ showed significant differences in adherence to the use of PPE by ICU nurses during endotracheal aspiration. The group of nurses who participated in educational activities (experimental) adhered to the use of protective aprons and glasses in 100\% of the activities. In turn, the group that did not participate in the educational activities (control) adhered to the use of glasses in 25\% of the activities and protective aprons in $87.5 \%$ of the times, corroborating the findings of the present study regarding the importance of this aspect for the promotion of adherence to SP by nursing workers.

Regarding the sociodemographic variable"had training on SP at the hospital", the present study found that the levels of adherence to SP were significantly higher in the group 
that reported having received such training compared to the group that did not receive the training. Other authors ${ }^{(6-7,73)}$ examined the relationship between adherence to SP and training on SP at the institution and also confirmed the importance of this aspect in the promotion of adherence to SP. One of these studies ${ }^{(13)}$ reported that the chance of using SP in the care to all patients was 34.63 times higher among nursing professionals who received training on SP at the health institution compared to those who did not receive such training $(95 \% \mathrm{Cl}: 11.74 ; 102.12)$.

Investing in periodic training on the use of PPE and proper disposal of potentially contaminated materials is needed to promote the use of the referred equipment, in order to reduce occupational exposure to biological agents among workers during manipulation of materials contaminated with blood and other body fluids ${ }^{(20)}$. Moreover educational actions are effective when they stimulate workers' reflection, promote their autonomy and encourage the adoption of protective measures for them and for the others ${ }^{(3,9)}$.

One limitation of this study is the small sample size, since data was collected in only one hospital, which may limit the generalization of the results obtained. Also, the inherent limitations of cross-sectional studies should be considered, as the design does not allow establishing a cause/effect relationship with greater accuracy.

\section{CONCLUSION}

It is concluded that there was only partial compliance with standard precautions by the nursing workers who perform their duties in a university hospital, and this is associated to individual, work-related and organizational factors. Each of these factors contributes to greater or lower adherence of the workers to the recommended safety measures.

Given the importance of ensuring full compliance with standard precautions, interventions should be designed to address these three types of factors concomitantly, considering the complexity of each of the aspects that impact workers' behavior within health organizations.

We recommend the implementation of permanent educational strategies that address aspects related to: 1- workers' perception of the risks they are exposed to; 2 - perception of the possible benefits of adopting preventive measures for workers' health and work safety; 3 - overcoming of the obstacles imposed by the peculiarities of nursing work. We believe that investing in problematizing educational approaches that attempt to impact these workers'perceptions, attitudes and behaviors, according to a situational diagnosis to be performed in each health institution, can bring positive results regarding the levels of compliance to SP by nursing workers.

In addition, university hospitals need to improve structural support for worker safety issues, through a permanent and adequate supply of PPE, and by seeking to create a workplace safety culture for nurses, so that workers and managers act in a co-responsible manner to improve health and safety conditions.

Further studies aimed to gain more insight on this phenomenon are recommended, as well as the presentation of educational and structural strategies to change this situation.

\section{口 REFERENCES}

1. Rodrigues OS, Sousa AFL, Magro MCS, Andrade D, Hermann PRS. Occupational accidents among nursing professionals working in critical units of an emergency service. Esc Anna Nery. 2017 [cited 2019 Feb 12];21(2):e20170040. Available from: http://www.scielo.br/scielo.php?script=sci_arttext\&pid=\$1414-81452 017000200212\&lng=en

2. Prüss-Üstün A, Rapiti E, Hutin Y. Estimation of the global burden of disease attributable to contaminated sharps injuries among health-care workers. Am J Ind Med. 2005;48(6):482-90. doi: https://doi.org/10.1002/ajim.20230

3. Valim MD, Marziale MHP, Hayashida M, Richart-Martínez M. Occurrence of occupational accidents involving potentially contaminated biological material among nurses. Acta Paul Enferm. 2014;27(3):280-6. doi: https://doi. org/10.1590/1982-0194201400047

4. Cunha QB, Camponogara S, Freitas E0, Pinno C, Dias GL, Cesar MP. Fatores que interferem na adesão às precauções padrão por profissionais da saúde: revisão integrativa. Enferm Foco. 2017;8(1):72-6. doi: https://doi.org/10.21675/2357707X.2017.v8.n1.980

5. Cunha QB. Adesão às precauções padrão por trabalhadores de enfermagem de um hospital universitário: estudo de métodos mistos [dissertação]. Santa Maria (RS): Universidade Federal de Santa Maria; 2017.

6. Brevidelli MM, Cianciarullo TI. Psychosocial and organizational factors relating to adherence to standard precautions. Rev Saude Pública. 2009 [citado 2019 fev 12];43(6):907-16. doi: https://doi.org/10.1590/S0034-89102009005000065

7. Carvalho MJ. Adesão às precauções-padrão por médicos residentes e fatores individuais, organizacionais e referentes ao trabalho [tese]. Santo André (SP): Faculdade de Medicina do ABC; 2016.

8. Piai-Moraes TH, Orland FS, Figueiredo RM. Factors influencing adherence to standard precautions among nursing professionals in psychiatric hospitals. Rev Esc Enferm USP. 2015;49(3):478-85. doi: https://doi.org/10.1590/S0080623420150000300016

9. Loro MM, Zeitoune RCG. Collective strategy for facing occupational risks of a nursing team. Rev Esc Enferm USP. 2017;51:e03205. doi: https://doi. org/10.1590/s1980-220x2015027403205

10. Martins RJ, Moimaz SAS, Sundefeld MLMM, Garbin AJl, Gonçalves PRV, Garbin CAS. Adherence to standard precautions from the standpoint of the Health Belief Model: the practice of recapping needles. Ciênc Saúde Coletiva. 2015;20(1):1938. doi: https://doi.org/10.1590/1413-81232014201.19822013 
11. Adinma ED, Ezeama C, Adinma II, Asuzu MC. Knowledge and practice of universal precautions against blood borne pathogens amongst house officers and nurses in tertiary health institutions in Southeast Nigeria. Niger I Clin Pract. 2009;12(4):398-402.

12. Carvalho REFL, Arruda LP, Nascimento NKP, Sampaio RL, Cavalcante MLSN, Costa ACP. Assessment of the culture of safety in public hospitals in Brazil. Rev Lat-Am Enfermagem. 2017;25:e2849. doi: https://doi.org/10.1590/1518-83 45.1600.2849

13. Felix AMS, Victor E, Malagutti SET, Gir E. Individual, work-related and institutional factors associated with adherence to standard precautions. J Infect Control. 2013 [cited 2019 Feb 12];2(2):106-11. Available from: http://jic-abih. com.br/index.php/jic/article/view/34/pdf__

14. Luo Y, He GP, Zhou JW, Luo Y. Factors impacting compliance with standard precautions in nursing, China. Int J Infect Dis. 2010;14(12):e1106-14. doi: https://doi.org/10.1016/j.ijid.2009.03.037

15. Quan M, Wang X, Wu H, Yuan X, Lei D, Jiang Z, Li L. Influencing factors on use of standard precautions against occupational exposures to blood and body fluids among nurses in China. Int J Clin Exp Med. 2015[cited 2019 Feb 12];8(12):22450-9. Available from: https://www.ncbi.nlm.nih.gov/pmc/ articles/PMC4730013/
16. Zhou Y, Zhang D, Chen Y, Zhou S, Pan S, Huang Y, et al. Healthcare-associated infections and Shanghai clinicians: a multicenter cross-sectional study. PLOS One. 2014;9(8):e0105838. doi: https://doi.org/10.1371/journal.pone.0105838

17. Sreedharan J, Muttappilymtalil J; Venkatramana M. Knowledge about standard precautions among university hospital nurses in the United Arab Emirates. East Mediterr Health J. 2011 [cited 2019 Feb 12];17(4):331-4. Available from: https://apps.who.int/iris/bitstream/handle/10665/118125/ 17_4_2011_0331_0334.pdf?sequence=1\&isAllowed=y

18. Atif, ML, Brenet A, Hageaux S, Fave MH, Cochet C, Baticle E, et al. Awareness of standard precautions for 4439 healthcare professionals in 34 institutions in France. Med Mal Infect. 2013;43(1):10-6. doi: https://doi.org/10.1016/j. medmal.2012.11.004

19. Day T, Wainwright SP, Wilson-Barnett J. An evaluation of a teaching intervention to improve the practice of endotracheal suctioning in intensive care units. J Clin Nurs. 2001;10(5):682-96. https://doi.org/10.1046/j.1365-2702.2001.00519.x

20. Dornelles C, Carvalho LA, Thoferhn MB, Nunes NJS, Fernandes HN. Exposição de profissionais de saúde ao material biológico: estudo no ambiente hospitalar. J Nurs Health. 2016;1(1):64-75. Disponível em: https://periodicos.ufpel.edu.br/ ojs2/index.php/enfermagem/article/view/5463

\section{- Corresponding author:}

Quézia Boeira da Cunha

E-mail: queziaqbc@gmail.com

\section{Associate editor:}

